\title{
Gerald "Charlie" Westbury
}

Developed new reconstructive procedures in cancer surgery

\author{
David Payne London
}

Emeritus professor of surgery (b 1927; q Westminster Medical School 1949; OBE, FRCP Lond, FRCS Eng, Hon FRCS Ed)

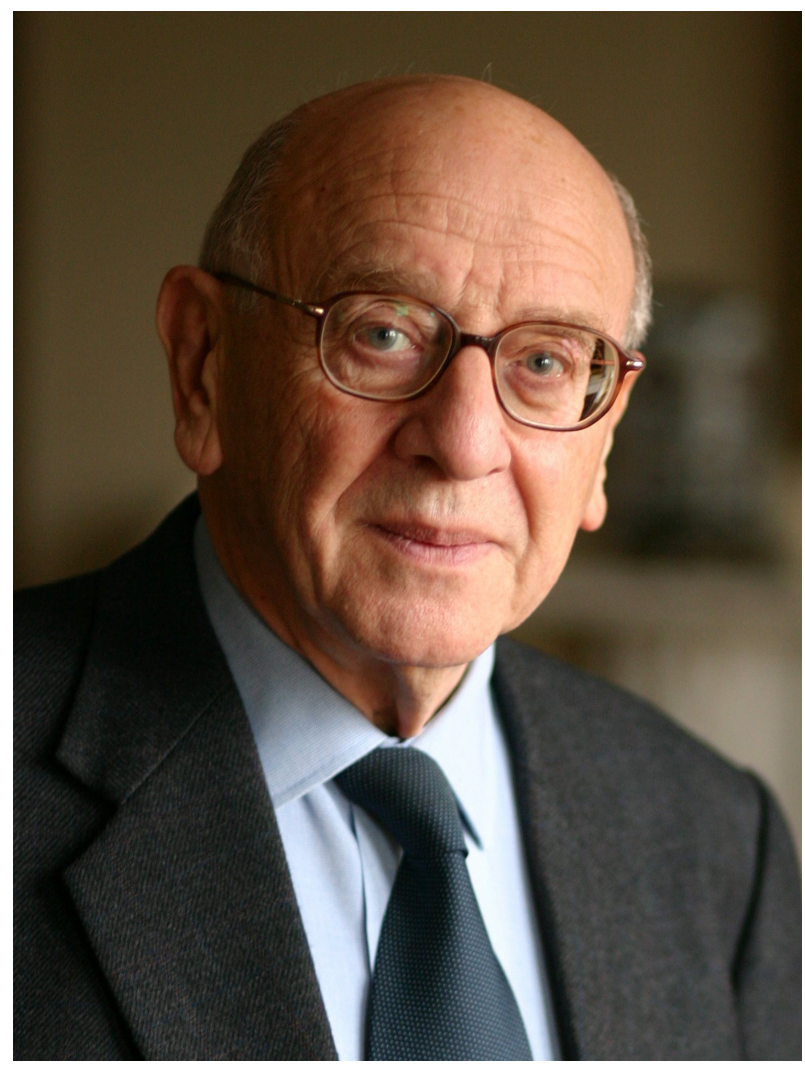

In the 20th century, Westminster Hospital in London became a centre for tertiary referrals for cancer, pioneering the multidisciplinary management of malignant disease. This approach was embodied by its Wednesday afternoon clinics, where it was not unusual for visiting clinicians and international experts to outnumber the patients whose interests were being discussed. ${ }^{1}$

The multidisciplinary ethos was led by Stanford Cade. Cade had a firm belief in exploring and using all treatment modalities, including the therapeutic use of radium and $x$ rays. In 1924 Cade obtained the UK's first supply of radium from the Radium Institute in Paris.

Gerald "Charlie" Westbury, who has died aged 86 (http://www. bmj.com/content/349/bmj.g5194), was Cade's registrar and senior registrar in the 1950s. Their association was to influence Westbury's entire career, which went on to include the development of new constructive procedures for cancers of the head and neck, and sarcomas, as well as continued advocacy of multidisciplinary working to deliver better results for patients. Westbury had worked as a resident surgical officer at the Brompton Hospital before arriving at Westminster. Cade valued Westbury's intellect and his broad knowledge of medicine as well as surgery, and was often heard to say "Westbury will know" when asked a question to which he did not know the answer. In 1960 Westbury succeeded Cade as consultant surgeon, having completed a fellowship at Harvard Medical School, where he studied the latest techniques in vascular surgery.

An early objective was to start a vascular surgery service. Westbury undertook the hospital's first aortic graft, using a sterilised terylene shirt tail shaped into a tube and pre-clotted with the patient's spilt blood.

His attention inevitably turned to cancer treatment, and he used his experience in vascular surgery to develop more complex procedures. Westbury challenged the orthodoxy that the more tissue that could be removed around a tumour the better, arguing that surgery should focus not only on curing, but also preserving physical function.

New reconstructive procedures were pioneered for cancers of the head and neck, including the "commando procedure" (COMbined MANDibulectomy and Neck Dissection Operation) for first degree malignancy of the tongue.

Working with a plastic surgeon colleague, Westbury developed remote skin flaps based on an artery to reconstruct the tissues, allowing surgery on the head, neck, and scalp to be undertaken with subsequent facial reconstruction.

In 1982 he became professor of surgery at the Royal Marsden Hospital and was dean of the Institute of Cancer Research (ICR) from 1982 to 1989. Westbury's daughter Charlotte, also an oncologist, said her father's firm belief in multidisciplinary working was matched by an appreciation of the importance of collaboration between science and medicine. 
She said: "My father was not himself a scientist, and I wonder if he sometimes regretted this, but he was ahead of his time in understanding translational medicine and communication between the two disciplines

"At the time that chromosomal translocations were being discovered in haematological malignancies, he realised that there may be similar changes in solid tumours and rather than wasting the tumour 'in the bucket' he initiated a project by suggesting to an ICR scientist that they look at the tissue, and they published one of the first articles on chromosomal translocations in sarcomas."

Her father, she said, was also ahead of his time in adopting a "humanistic" approach to patient communication, at a time when surgeons were stereotyped for delivering blunt messages to patients about a proposed course of action. "He had great respect for individuals and for patients. He wanted subconsciously for them to have the best experience, and that involved his communication as well as his decision making."

Charlotte Westbury recounts how her father once advised a colleague to tell a patient, "I have a little bit of concern," instead of "I'm really worried about this." She added: "He just turned it round because he knew how best to give the patient the information without worrying them."

Her father had a humble start in life. His parents were of East European Jewish origin and ran a tailor's shop just off the Edgware Road in London. As a child he turned down a scholarship place at Christ's Hospital in Sussex, ostensibly because he didn't fancy the school's uniform of a belted long blue coat, knee breeches, and yellow socks.

Instead he went to St Marylebone Grammar, before he and his younger brother were evacuated to Redruth, Cornwall.

In June 1944 he was back in London, sitting exams as part of his early studies. During one practical exam in physics, a German VI "flying bomb" exploded outside the nearby National History Museum. The students dived under the laboratory benches and were promised lenient marking because of the interruption. Westbury maintained he would never have passed the exam otherwise.
He won the surgery prize at Westminster and gained honours in the London MB exam in 1949. He also established the "18 club" for his undergraduate cohort, which met annually for 65 years until 2013. His dry wit and sense of humour-he insisted on listening to BBC radio comedy The Goon Show between surgical cases-earned him the lifelong sobriquet "Charlie."

Other achievements included a Hunterian professorship in 1963; the Honeyman Gillespie lecture in Edinburgh in 1965; the Gordon-Taylor, Semon, and Haddow lectures at the Royal Society of Medicine; and the Walker prize of the Royal College of Surgeons in 1990.

He was honorary consultant in surgery to the army from 1980 to 1992; president of the British Association of Surgical Oncology from 1989 to 1992; and examiner at the universities of London, Cambridge, Edinburgh, and Hong Kong. He was appointed OBE in 1990.

In retirement Westbury was a trustee for several charities and for seven years chaired the UK branch of Magen David Adom, Israel's equivalent to the Red Cross. In 1995 he became a founding fellow of the UK charity Breakthrough Breast Cancer, helping to lead a $£ 15 \mathrm{~m}$ appeal to create the new Breakthrough Toby Robins Breast Cancer Research Centre.

His family and colleagues remember a man of quiet and persuasive authority, who was widely read and had an encyclopaedic knowledge of classical music and traditional jazz-an enthusiasm he shared with his brother, Harry, a retired radiologist who worked at Harefield Hospital. He also loved walking and birdwatching.

His Durban born wife Hazel died in 2013. They met when Westbury treated her mother, who inquired if the flowers in his clinic had been arranged by his wife. When he confirmed his bachelor status, he was invited for dinner. He married Hazel in 1965.

Westbury leaves three daughters.

Retsas S. The treatment of melanoma at Westminster Hospital in the 20th century. JBUON 2013;18(2):537-41

Cite this as: BMJ 2014;349:g6405

(c) BMJ Publishing Group Ltd 2014 